\title{
Tinjauan yuridis terhadap pengaturan terkait pekerja harian lepas
}

\author{
Rakhman Candra Suryaningrat ${ }^{1}$, Mohammad Ghufron $\mathrm{Az}^{2}$, Supriyadi ${ }^{3}$.
}

${ }^{1}$ Rakhman Candra Suryaningrat; Program Studi Magister Hukum Pascasarjan Universitas Merdeka Malang; Jl. Terusan Raya Dieng Nomor 62-64; Malang; 65146; Jawa Timur; Indonesia.

${ }^{2}$ Mohammad Ghufron Az; Fakultas Hukum Universitas Merdeka Malang; Jl. Terusan Raya Dieng Nomor 62-64; Malang; 65146; Jawa Timur; Indonesia.

${ }^{3}$ Supriyadi; Fakultas Hukum Universitas Merdeka Malang; Jl. Terusan Raya Dieng Nomor 62-64; Malang; 65146; Jawa Timur; Indonesia.

\begin{tabular}{l} 
A R T I C L E I N F O \\
\hline Article history: \\
Received 2021-04-19 \\
Received in revised form \\
2021-07-18 \\
Accepted 2021-08-01 \\
\hline
\end{tabular}

Kata kunci:

Pekerja; Perjanjian; Sengketa.

Keywords:

Worker; Agreement; Dispute.

DOI: $h$ ttps://doi.org/10.26905/

idjch.v12i2.5813.

How to cite item:

Suryaningrat, RC., Ghufron Az, M \& Supriyadi (2021). Tinjauan yuridis terhadap pengaturan terkait pekerja harian lepas. Jurnal Cakrawala Hukum, 12(2), 213-222 doi:10.26905/idjch.v12i2.5813.

Corresponding Author:

* Rakhman Candra Suryaningrat.

E-mail address: candra@sagagroup.co.id

\section{Abstrak}

Tenaga pekerja/buruh seringkali diperas oleh pengusaha dengan upah yang relatif kecil. Hubungan kerja pada dasarnya adalah hubungan antara pekerjalburuh dan pengusaha setelah adanya perjanjian kerja. Adapun rumusan permsasalahan yang dibahas dalam penulisan ini adalah bagaimanakah pengaturan mengenai pekerja harian lepas yang ada di Indonesia dan bagaimanakah penyelesaian sengketa terkait perjanjian kerja terhadap pekerja harian lepas yang ada di Indonesia. Hasil penelitian dari rumusan masalah tersebut adalah Pengaturan mengenai pekerjal buruh harian lepas diatur di dalam Peraturan perundang-undangan, di dalam undang-undang nomor 13 tahun 2003 tentang ketenagakerjaan di dalam Pasal 56 sampai dengan Pasal 59, namun terdapat beberapa pasal yang diubah oleh Undangundang Nomor 11 Tahun 2020 tentang cipta kerja. Penyelesaian sengketa antara pengusaha dengan pekerja/buruh harian lepas dapat diselesaikan dahulu secara musyawarah untuk mufakat sesuai dengan yang sudah diatur di dalam Pasal 136 ayat (1) Undang-Undang Nomor 13 Tahun 2003 tentang Ketenagakerjaan, namun apabila upaya musyawarah untuk mufakat tidak tercapai maka pengusahan dan pekerja/buruh atau serikat pekerja/serikat buruh menyelesaikan perselisihan hubungan industrial.

\[ \text { Abstract } \]
Workers / laborers are often extorted by employers with relatively small wages. An
employment relationship is basically a relationship between a worker / laborer and
an entrepreneur after a work agreement is made. The formulation of the problems
discussed in this paper is how to regulate freelance daily workers in Indonesia and


how to resolve disputes related to work agreements for casual daily workers in Indonesia. The result of the research on the formulation of the problem is that the regulation regarding freelance workers / laborers is regulated in statutory regulations, in law number 13 of 2003 concerning manpower in Article 56 to Article 59, but there are several articles amended by-Law Number 11 of 2020 concerning work copyright. Settlement of disputes between employers and workers / casual daily laborers can be resolved first by deliberation to reach a consensus in accordance with what has been stipulated in Article 136 paragraph (1) of Law Number 13 of 2003 concerning Manpower, but if deliberation efforts to reach consensus cannot be reached then the management and workers/laborers or trade/labor unions resolve industrial relations disputes.

\section{Pendahuluan}

Berbicara mengenai ketenagakerjaan tersebut tentunya ada pihak-pihak yang terlibat didalamnya yang akan menimbulkan terselenggaranya hubungan industrial yaitu pekerja/buruh, pengusaha dan pemerintah. Upaya menciptakan hubungan industrial adalah dalam rangka mencari keseimbangan antara kepentingan pekerja/buruh, pengusaha dan pemerintah, karena ketiga komponen ini mempunyai masing-masing kepentingan.

Bagi pekerja/buruh, perusahaan merupakan tempat untuk bekerja sekaligus sebagai sumber penghasilan dan penghidupan diri beserta keluarganya. Bagi pengusaha, perusahaan adalah wadah untuk mengeksploitasi modal guna mendapat keuntungan yang sebesar-besarnya. Bagi pemerintah, perusahaan sangat penting artinya karena perusahaan besar maupun kecil merupakan bagian dari kekuatan ekonomi yang menghasilkan barang atau jasa untuk memenuhi kebutuhan masyarakat, karena itulah pemerintah mempunyai kepentingan dan bertanggungjawab atas kelangsungan dan keberhasilan setiap perusahaan serta pemerintah mempunyai peranan sebagai pengayom, pembimbing, pelindung dan pendamai bagi seluruh pihak dalam masyarakat pada umumnya dan pihak-pihak yang terkait dalam proses produksi pada khususnya.

Didalam dunia usaha, faktor tenaga kerja sangat dominan berpengaruh terhadap kelancaran operasional suatu perusahaan. Kualitas tenaga kerja dapat menjadi penentu atas kualitas produk yang dihasilkan oleh suatu obyek usaha yang diminati pasar, namun disisi lain tenaga kerja yang berkualitas perlu mendapatkan perlindungan hukum secara riil dan hak-haknya tidak terabaikan. Untuk mendukung hal tersebut, maka pada tanggal 25 Maret 2003 Pemerintah Republik Indonesia telah mengesahkan Undang-Undang Republik Indonesia Nomor 13 tahun 2003 Tentang Ketenagakerjaan.

Dengan demikian, hubungan industrial yang didasarkan atas keserasian, keselarasan dan keseimbangan pihak-pihak yang terkait dalam proses produksi akan berjalan dengan baik. Hal ini dimaksudkan untuk menjamin hak-hak dasar pekerja/buruh dan menjamin kesamaan kesempatan serta perlakuan tanpa diskriminasi atas dasar apapun untuk mewujudkan kesejahteraan pekerja/ buruh dan keluarganya.

Perlindungan terhadap tenaga kerja dituangkan dalam Pasal 28 D ayat (2) UUD 1945 dan Pasal 38 ayat (1), (2), (3) dan (4) UndangUndang No 39 Tahun 1999 tentang Hak Asasi Manusia yang menyatakan bahwa: Pasal 28 D ayat (2) UUD 1945, yang berbunyi: Setiap orang berhak untuk bekerja serta mendapat imbalan dan perlakuan yang adil dan layak dalam hubungan kerja.

Perlindungan hukum terhadap pekerja/ buruh merupakan pemenuhan hak dasar yang 
melekat dan dilindungi oleh konstitusi sebagaimana yang diatur di dalam Pasal 27 ayat 2 Undang Undang Dasar 1945 “Tiap-tiap warga negara berhak atas pekerjaan dan penghidupan yang layak bagi kemanusiaan" dan Pasal 33 ayat 1 yang menyatakan bahwa "perekonomian disusun sebagai usaha bersama atas kekeluargaan". Pelanggaran terhadap hak dasar yang dilindungi oleh konstitusi merupakan pelanggaran hak asasi manusia (Lalu Husni, 2003). Perlindungan terhadap tenaga kerja dimaksudkan untuk menjamin hak-hak dasar para pekerja/buruh dan menjamin kesamaan serta perlakuan tanpa diskriminasi atas dasar apapun untuk mewujudkan kesejahteraan pekerja dan keluarganya dengan tetap memperhatikan perkembangan kemajuan dunia usaha dan kepentingan pengusaha. Peraturan perundangundangan yang terkait dengan perlindungan bagi para pekerja UndangUndang nomor 13 tahun 2003 tentang Ketenagakerjaan dan peraturan pelaksana dari perundang-undangan di dalam bidang Ketenagakerjaan.

Permasalahan ketenagakerjaan di Indonesia yang sering kali terjadi terkait mengenai hubungan kerja yang tidak seimbang antara pengusaha dengan pekerja/buruh adalah dalam hal pembuatan perjanjian kerja. Bukan hanya tidak seimbang dalam membuat perjanjian kerja, akan tetapi iklimpersaingan usaha yang makin ketat juga dapat menyebabkan perusahaan melakukan efesiensi biaya produksi (cost of production). (Suwarno, 2000)

Persoalan ketenagakerjaan bukan sematamata soal melindungi pihak yang perekonomiannya yang lemah terhadap pihak yang perekonomiannya kuat untuk mencapai adanya keseimbangan antara kepentingan yang berlainan melainkan juga soal menemukan jalan dan cara yang sebaik-baiknya dengan tidak meninggalkan sifat kepribadian dan kemanusian bagi setiap orang yang melakukan pekerjaan untuk mendapatkan hasil yang sebanyak-banyaknya dari tiap pekerjaan yang sudah ditentukan menjadi tugasnya dan sebagai imbalan atas jerih payahnya itu untuk mendapatkan penghidupan yang layak bagi kemanusiaan.

Dalam hubungan antara pekerja/buruh dan pengusaha, secara yuridis pekerja/buruh dipandang sebagai orang yang bebas karena prinsip negara kita tidak seorangpun boleh diperbudak. Secara sosiologis pekerja/ buruh itu tidak bebas sebagai orang yang tidak mempunyai bekal hidup yang lain selain tenaganya. Pekerja/buruh kadangkadang terpaksa untuk menerima hubungan kerja dengan pengusaha meskipun memberatkan bagi pekerja/buruh itu sendiri, lebih-lebih saat sekarang ini dengan banyaknya jumlah tenaga kerja yang tidak sebanding dengan lapangan pekerjaan yang tersedia.

Akibatnya tenaga pekerja/buruh seringkali diperas oleh pengusaha dengan upah yang relatif kecil. Hubungan kerja pada dasarnya adalah hubungan antara pekerja/buruh dan pengusaha setelah adanya perjanjian kerja. Perjanjian kerja merupakan awal dimulai suatu hubungan kerja yang dibuat atas pernyataan kesanggupan antara pekerja/buruh dengan pengusaha.

\section{Metode}

Jenis penelitian yang digunakan, yaitu penelitian hukum normatif, yang bertujuan mengetahui sejauh mana hukum dapat bekerja dan mengatur terkait pekerja harian lepas.

\section{Pembahasan}

\subsection{Pengaturan terhadap pekerja harian lepas di Indonesia}

Pekerja harian lepas adalah pekerja yang bekerja berdasarkan perjanjian kerja hariap atau lepas dan merupakan jenis perjanjian kerja yang penggunaannya legal dan diatur undang-undang sebagai Perjanjian Kerja Waktu Tertentu (PKWT) dengan syarat kerja tertentu, termasuk manfaat 
dan tunjangan. Akan tetapi pada praktiknya perusahaan bisa saja berhadapan dengan berbagai risiko seperti risiko legal, bisnis, dan reputasi akibat ketidaksesuaian implementasi dengan peraturan yang berlaku atau standar ketenagakerjaan lainnya.

Ketentuan yang mengatur hubungan kerja antara pemberi kerja dan penerima kerja beserta akibatnya diatur di dalam Undang-Undang Nomor 13 Tahun 2003 tentang Ketenagakerjaan (yang selanjutnya disebut sebagai Undang-Undang Ketenagakerjaan) beserta dengan peraturan pelaksanaannya. Di dalam undang-undang ketenagakerjaan dikenal dua bentuk perjanjian kerja yaitu Perjanjian Kerja Waktu Tertentu (PKWT) dan Perjanjian Kerja Waktu Tidak Tertentu (PKWTT) sebagaimana diatur di dalam Pasal 56 ayat (1) Undang-Undang Ketenagakerjaan, sedangkan di dalam Pasal 56 ayat (2) bahwa pelaksanaan Perjanjian Kerja Waktu tertentu (PKWT) didasarkan pada jangka waktu dan selesainya suatu pekerjaan tertentu.

Ketentuan mengenai PKWT diatur di dalam Pasal 56 sampai dengan Pasal 59 undang-undang ketenagakerjaan dimana pada tahun 2020 ini Pemerintah telah mengesahkan Undang-Undang Nomor 11 Tahun 2020 tentang Cipta Kerja dimana undang-undang tersebut merubah beberapa ketentuan pasal-pasal di dalam Undang-undang ketenagakerjaan. Adapun Pasal 59 undang-undang ketenagakerjaan yang dirubah oleh Pasal 81 angka 15 diantaranya: 1) Perjanjian kerja untuk waktu tertentu hanya dapat dibuat untuk pekerjaan tertentu yang menurut jenis dan sifat atau kegiatan pekerjaannya akan selesai dalam waktu tertentu, yaitu sebagai berikut: a). Pekerjaan yang sekali selesai atau yang sementara sifatnya; b) Pekerjaan yang diperkirakan penyelesainnya dalam waktu yang tidak terlalu lama; c) Pekerjaan yang bersifat musiman; d) Pekerjaan yang berhubungan dengan produk baru, kegiatan baru, atau produk tambahan yang masih dalam percobaan atau penja- jakan; atau e) Pekerjaan yang jenis dan sifat atau kegiatannya bersifat tidak tetap. 2) Perjanjian kerja untuk waktu tertentu tidak dapat diadakan untuk pekerjaan yang bersifat tetap. 3) Perjanjian kerja untuk waktu tertentu yang tidak memenuhi ketentuan sebagaimana dimaksud pada ayat (1) dan (2) demi hukum menjadi perjanjian kerja waktu tidak tertentu. 4) Ketentuan lebih lanjut mengenai jenis dan sifat atau kegiatan pekerjaan, jangka waktu dan batas waktu perpanjangan perjanjian kerja waktu tertentu diatur di dalam Peraturan Pemerintah.

Dari ketentuan tersebut diatas terdapat beberapa ayat yang dirubah pengaturannya diantaranya pertama dihapusnya ketentuan Pasal 59 ayat (1) huruf b undang-undang ketenagakerjaan mengenai batas maksimum jangka waktu pekerjaan yang diperbolehkan menggunakan perjanjian kerja waktu tertentu, kedua adanya tambahan ketentuan dalam Pasal 59 ayat (1) yaitu mengenai jenis dan sifat pekerjaan yang dapat menggunakan PKWT yaitu tercantum dalam Pasal 81 angka 15 ayat (1) huruf e undang-undang nomor 11 tahun 2020 tentang cipta kerja, ketiga dihapuskannya ketentuan Pasal 59 ayat (3) sampai dengan ayat (8), dimana ketentuan lebih lanjut mengenai PKWT akan diatur dalam Peraturan Pemerintah, bukan di dalam sebuah Keputusan Menteri.

Namun sampai dengan saat Peraturan Pemerintah yang diamanatkan di dalam Pasal 81 angka 15 ayat (4) masih belum terbit, sehingga untuk pengaturan pelaksana mengenai PKWT masih menggunakan Keputusan Menteri Tenaga Kerja dan Transmigrasi Republik Indonesia Nomor Kep.100/MEN/VI/2004 tentang Ketentuan Pelaksanaan Perjanjian Kerja Waktu Tertentu (yang selanjutnya disebut dengan Kepmen No.100/2004).

Kepmen No.100/2004 merupakan peraturan pelaksanaan dari undang-undang ketenagakerjaan mengenai Perjanjian kerja waktu tertentu (PKWT), yang di dalamnya juga mengatur mengenai pekerja harian lepas, sehingga dapat dikatakan bahwa 
menurut Kepmen ini perjanjian kerja harian lepas merupakan bagian dari PKWT. Dalam Kepmen No.100/2004 ketentuan mengenai perjanjian kerja harian lepas diatur di dalam pasal 10 sampai dengan Pasal 12. Namun demikian, perjanjian kerja harian lepas ini juga mengecualikan beberapa ketentuan umum mengenai PKWT, yang mana beberapa persyaratan mengenai perjanjian pekerja harian lepas diantaranya adalah: 1) Perjanjian kerja harian lepas dilaksanakan untuk pekerjaan-pekerjaan tertentu yang berubah-ubah dalam hal waktu dan volume serta upah didasarkan pada kehadiran; 2) Perjanjian kerja harian lepas dilakukan dengan ketentuan pekerja/burug bekerja kurang dari 21 (dua puluh satu) hari dalam 1 (satu) bulan; 3) Dalam hal pekerja/buruh bekerja lebih dari 21 (dua puluh satu) hari atau lebih selama 3 (tiga) bulan berturut-turut atau lebih maka perjanjian kerja harian lepas berubah menjadi Perjanjian Kerja Waktu Tidak Tertentu (PKWTT).

Di dalam Pasal 12 Kepmen No.100/2004 diatur mengenai perjanjian kerja harian lepas diantaranya adalah: 1) Pengusaha diwajibkan membuat perjanjian kerja harian lepas secara tertulis dengan pekerja/buruh yang menerima pekerjaan tersebut; 2) Pengusaha harus menyampaikan daftar pekerja/buruh kepada instansi yang bertanggung jawab di bidang ketenagakerjaan setempat selambat-lambatnya 7 (tujuh) hari kerja sejak mempekerjakan pekerja/buruh.

Setiap pekerja harian lepas juga mempunyai hak seperti pekerja-pekerja lainnya, hak-hak dari pekerja harian lepas diantaranya adalah: 1) Hak untuk mendapatkan upah dimana terdapat dua macam skema upah pada pekerja harian lepas yaitu upah berdasarkan waktu dan upah berdasarkan hasil sebagaimana yang diatur di dalam Pasal 12 Peraturan Pemerintah Republik Indonesia Nomor 78 Tahun 2015 tentang Pengupahan; 2) Hak untuk mendapatkan Tunjangan Hari Raya (THR) sebagaimana diatur di dalam Peraturan Menteri Ketenagakerjaan Nomor 6 Tahun 2016 tentang Tunjangan
Hari Raya Keagamaan Bagi Pekerja/Buruh di Perusahaan, dimana dalam peraturan tersebut diatur bahwa semua pekerja berhak atas Tunjangan Hari Raya; 3) Hak untuk mendapatkan tunjangan sosial atau BPJS Ketenagakerjaan dimana setiap pengusaha yang mempunyai pekerja baik pekerja harian lepas diwajibkan untuk mengikutsertakan pekerjanya kedalam jaminan nasional bagi pengusaha yang mempunyai pekerja minimal sepuluh orang atau bagi perusahaan yang telah membayar upah minimal sebesar Rp.1.000.000,- (satu juta rupiah) dalam sebulan, pengaturan tersebut tercantum di dalam Pasal 2 ayat (1) Keputusan Menteri Tenaga Kerja Nomor KEP-150/MEN/1999 tentang Penyelenggaraan Program Jaminan Sosial Tenaga Kerja bagi Tenaga Kerja Harian Lepas, Borongan, dan PKWT yang berbunyi " setiap pengusaha yang mempekerjakan tenaga harian lepas, borongan dan PKWT wajib mengikutsertakan tenaga kerjanya dalam program jaminan sosial tenaga kerja kepada Badan penyelenggaran. Terdapat tambahan bagi pekerja harian lepas maupun pekerja PKWT dalam sektor industri konstruksi wajib didaftarkan sebagai Jaminan Kematian (JKM) atau Jaminan Kecelakaan Kerja (JKK).

Pekerja harian lepas berhak untuk bergabung menjadi anggota serikat pekerja/ serikat buruh, yang artinya bahwa pekerja harian lepas juga memiliki hak dan kebebasan untuk bergabung atau tidak dengan serikat pekerja/serikat buruh dan untuk terlibat atau tidak terlibat dalam penyusunan perjanjian kerja bersama, ketentuan tersebut diatur di dalam Pasal 104 Undang-undang Ketenagakerjaan.

\subsection{Penyelesaian sengketa terkait [erjanjian kerja terhadap pekerja harian lepas di In- donesia}

Penyelesaian perselisihan industrial merupakan masalah yang sangat penting dalam hubungan industrial. Hubungan industrial yang 
harmonis akan menciptakan ketenangan kerja yang akan berpengaruh pula pada peningkatan produktifitas dan kesejahteraan pekerja. Namun demikian, dalam kenyataannya tidak mudah untuk mewujudkan hubungan industrial yang harmonis tadi, karena adanya kepentingan yang berbeda antara pekerja disatu pihak dan pengusaha dipihak lain.

Istilah hubungan industrial berasal dari kata industrial relation, merupakan perkembangan dari istilah hubungan perburuhan (labour relation atau labour management relations). Menurut Sentanoe Kertonegoro, istilah hubungan perburuhan memberi kesan yang sempit seakan-akan hanya menyangkut hubungan antara pengusaha dan pekerja.

Hubungan insdutrial memiliki sebuah fungsi dimana fungsi masing-masing pihak yang melaksanakan hubungan industrial yaitu: pemerintah, pekerja/buruh atau serikat pekerja/serikat buruh dan pengusaha. Berdasarkan Pasal 102 ayat (1) Undang-Undang Ketenagakerjaan, fungsi pemerintah dalam melaksanakan hubungan industrial adalah: menetapkan kebijakan; memberikan pelayanan; melaksanakan pengawasan; dan melakukan penindakan terhadap pelanggaran peraturan perundang-undangan ketenagakerjaan.

Berdasarkan Pasal 102 ayat (2) UndangUndang Ketenagakerjaan fungsi pekerja/buruh dan serikat pekerja/serikat buruh dalam melaksanakan hubungan industrial adalah: 1) Menjalankan pekerjaan sesuai dengan kewajibannya; 2) Menjaga ketertiban demi kelangsungan produksi; 3) Menyalurkan aspirasi secara demokratis; 4) Mengembangkan ketrampilan dan keahliannya serta ikut memajukan perusahaan, dan 5) Memperjuangkan kesejahteraan anggota beserta keluarganya.

Selanjutnya berdasarkan ketentuan Pasal 102 ayat (3) Undang-Undang Ketenagakerjaan, fungsi pengusaha dalam melaksanakan hubungan industrial adalah: menciptakan kemitraan; mengembangkan usaha; memperluas lapangan kerja; dan memberikan kesejahteraan pekerja/buruh secara terbuka, demokratis dan berkeadilan.

Hubungan Industrial di Indonesia, menurut Abdul Khakim mempunyai perbedaan dengan yang ada di negara lain. Ciri-ciri itu adalah sebagai berikut (Abdul Hakim, 2003): 1) Mengakui dan meyakini bahwa bekerja bukan sekedar mencari nafkah saja, tetapi sebagai pengabdian manusia kepada Tuhannya, sesama manusia, masyarakat, bangsa dan Negara; 2) Menganggap pekerja bukan sebagai faktor produksi, melainkan sebagai manusia yang bermartabat; 3) Melihat antara pengusaha dan pekerja bukan dalam perbedaan kepentingan, tetapi mempunyai kepentingan yang sama untuk memajukan perusahaan.

Secara umum terdapat lima sistem hubungan industrial, yaitu sebagai berikut (Abdul Hakim, 2003): 1) Sistem hubungan industrial atas dasar kegunaan (utility system). Pada bagian ini hubungan perburuhan diatur sedemikian rupa, sehingga utility buruh dapat digunakan sepenuhnya. Ada kebijaksanaan full employment of man power. Buruh diberi upah dan jaminan yang tinggi apabila ia dapat memberikan tenaganya dengan maksimal. Tenaga mereka diperas untuk mencapai produksi yang sebesar-besarnya. 2) Sistem hubungan industrial atas dasar demokrasi (Democratic system). Sistem ini mengutamakan konsultasi atau musyawarah antara buruh dan majikan. 3) Sistem hubungan industrial atas dasar kemanusiaan $(\mathrm{Hu}-$ man system). Sistem ini tidak begitu memperhitungkan peningkatan produktivitas dan efisiensi. 4) Sistem hubungan industrial atas dasar komitmen seumur hidup (life long commitment/life time employment). Sistem ini terdapat di Jepang. Buruh cenderung setia kepada majikan, baik perusahaan dalam keadaan untung atau rugi. Buruh mempunyai disiplin yang tinggi, bekerja keras dengan penuh dedikasi. Di pihak lain majikan memperlakukan buruhnya sebagai anak dan dianggap keluarga, dengan memberikan fasilitas-fasilitas. 5) Sistem hubungan industrial atas dasar perjuangan kelas. 
Muncul atas ide dari Karl Marx dimana terdapat pertentangan kelas pemilik modal (kapitalis). Semakin tajam pertentangan maka semakin cepat diselesaikan dengan membinasakan kapitalis oleh proletar yang lapar yang menuntut keadilan.

Terdapat beberapa jenis perselisihan hubungan industrial, berdasarkan beberapa literatur diantaranya: 1) Perselisihan hak (rechtsgeschillen) Yaitu perselisihan yang timbul karena salah satu pihak tidak memenuhi isi perjanjian kerja, peraturan perusahaan, perjanjian perburuhan atau ketentuan peraturan perundangan. 2) Perselisihan kepentingan (belangengeschillen) Yaitu perselisihan yang terjadi akibat dari perubahan syarat-syarat perburuhan atau yang timbul karena tidak ada persesuaian paham mengenai syarat-syarat kerja dan atau keadaan perburuhan.

Berdasarkan sifatnya perselisihan dibagi menjadi dua macam, yaitu: 1) Perselisihan perburuhan kolektif Yakni perselisihan terjadi antara pengusaha/majikan dengan serikat pekerja/ serikat buruh, karena tidak adanya persesuaian paham mengenai hubungan kerja, syaratsyarat kerja dan/atau keadaan perburuhan. 2) Perselisihan perburuhan perseorangan Yakni perselisihan antara pekerja/buruh yang tidak menjadi anggota serikat pekerja atau serikat buruh dengan pengusaha/majikan.

Berdasarkan Ketentuan Pasal 2 Undangundang Nomor 2 Tahun 2004 tentang Penyelesaian Perselisihan Hubungan Industrial bahwa jenis perselisihan hubungan industrial meliputi empat macam: 1) Perselisihan hak, yaitu perselsihan yang timbul karena tidak dipenuhinya hak, akibat adanya perbedaan pelaksanaan atau penafsiran terhadap ketentuan peraturan perundang-undangan, perjanjian kerja, peraturanperusahaan, atau perjanjian kerja bersama. (Pasal 1 angka 2) 2) Perselisihan kepentingan, yaitu perselisihan yang timbul dalam hubungan kerja karena tidak adanya kesesuaian pendapat mengenai pembuatan, dan/ atau perubahan syarat-syarat kerja yang ditetapkan dalam perjanjian kerja, atau peraturan perusahaan, atau perjanjian kerja bersama (Pasal 1 angka 3). 2) Perselisihan pemutusan hubungan kerja, yaitu perselisihan yang timbul karena tidak adanya kesesuaian pendapat mengenai pengakhiran hubungan kerja yang dilakukan oleh salah satu pihak (Pasal 1 angka 4). 3) Perselisihan antar serikat pekerja/serikat buruh hanya dalam satu perusahaan, yaitu perselisihan antara serikat pekerja/ serikat buruh dengan serikat pekerja/serikat buruh lain hanya dalam satu perusahaan karena tidak adanya persesuaian paham mengenai keanggotaan, pelaksanaan hak dan kewajiban keserikat-pekerjaan (Pasal 1 angka 5).

Sesuai dengan tata hukum di Indonesia Pasal 1 angka 1 Undang-undang Nomor 2 tahun 2004 tentang Penyelesaian Perselisihan Hubungan Industrial (yang selanjutnya akan disebut UndangUndang PHI), memberikan pengertian tentang perselisihan hubungan industrial adalah perbedaan pendapat yang mengakibatkan pertentangan antara pengusaha atau gabungan pengusaha dengan pekerja/buruh atau serikat pekerja/serikat buruh karena adanya perselisihan mengenai hak, perselisihan kepentingan, perselisihan pemutusan hubungan kerja dan perselisihan antar serikat pekerja/serikat buruh dalam satu perusahaan.

Prinsip yang harus menjadi pegangan bagi para pihak dalam menyelesaikan perselisihan hubungan industrial adalah: 1) Wajib dilaksanakan oleh pengusaha dan pekerja/buruh atau serikat pekerja/seikat buruh secara musyawarah untuk mufakat (Pasal 136 ayat (1) Undang-Undang Ketenagakerjaan). 2) Bila upaya musyawarah untuk mufakat tidak tercapai, maka pengusaha dan pekerja/buruh atau serikat pekerja/serikat buruh menyelesaikan perselisihan hubungan industrial melalui prosedur yang diatur undang-undang (Pasal 136 ayat (2) Undang-Undang Ketenagakerjaan).

Dalam bidang perburuhan timbulnya perselisihan antara pengusaha dengan para buruh 
biasanya berpangkal karena perasaan-perasaan kurang puas terhadap hak atau kebijakan-kebijakan yang diberikan oleh pengusaha (Zainal Asikin, 2006). Setiap perselisihan hubungan industrial wajib diupayakan penyelesaiannya terlebih dahulu melalui perundingan Bipartit dan jika perundingan mencapai hasil dibuatkan Persetujuan Bersama (PB) dan apa bila tidak tercapai kesepakatan maka dapat dilakukan upaya Bipartit, mediasi, konsiliasi, dan arbitrase.

Penyelesaian melalui Bipartit, pada awalnya setiap penyelesaian perselisihan hubungan industrial diselesaikan melalui musyawarah untuk mufakat oleh para pihak yang berselisih sendiri atau disebut mekanisme Bipartit. Penyelesaian Bipartit dilakukan agar perselisihan dapat dilaksankan secara kekeluargaan, yang diharapkan masingmasing pihak tidak merasa ada yang dikalahkan atau dimenangkan, karena penyelesaian Bipartit bersifat mengikat. Undang-Undang memberikan waktu paling lama 30 hari untuk penyelesaian melalui lembaga ini, jika lebih dari 30 hari maka perundingan Bipartit dianggap gagal, apabila perundingan mencapai kesepakatan, wajib dibuat perjanjian bersama yang berisikan hasil perundingan. (Zainal Asikin, 2006)

Sebaliknya jika tidak tercapai kesepakatan, harus dibuat risalah perundingan sebagai bukti telah dilakukan perundingan Bipartit. Dalam hal perundingan Bipartit gagal, salah satu pihak wajib mencatatkan perselisihannya kepada instansi yang bertanggung jawab dibidang ketenagakerjaan setempat untuk diperantarai. Pejabat yang berwenang pada instansi tersebut wajib menawarkan para pihak untuk menawarkan penyelesaian melalui konsiliasi untuk perselisihan kepentingan, pemutusan hubungan kerja atau perselisihan antar serikat pekerja/buruh disuatu perusahaan, atau penyelesain melalui arbitrase untuk perselisihan kepentingan dan perselisihan antar serikat pekerja/buruh di suatu perusahaan.
Ketentuan Pasal 6 dan Pasal 7 UndangUndang No. 2 Tahun 2004 tentang Penyelesaian Perselisihan Hubungan Industrial memberi jalan penyelesaian sengketa pekerja/buruh dan tenaga kerja berdasarkan musyawarah mufakat dengan mengutamakan asas kekeluargaan antara buruh dan majikan. Apabila terdapat kesepakatan antara pekerja/buruh dan majikan atau antara serikat pekerja dengan majikan, dapat dituangkan dalam perjanjian kesepakatan kedua belah pihak yang disebut perjanjian bersama.

Penyelesaian melalui mediasi, pada dasarnya perselisihan industrial melalui mediasi adalah wajib, manakala para pihak tidak memilih penyelesaian melalui konsiliasi atau arbiter setelah instansi yang bertanggung jawab di bidang ketenagakerjaan menawarkan kepada pihak-pihak yang berselisih.

Apabila proses penyelesaian mediasi tidak tercapai kesepakataan, mediator menyampaikan anjuran secara tertulis untuk memberikan pendapat dalam penyelesaiannya. Selanjutnya para pihak harus memberikan jawaban tertulis atas anjuran tersebut, yang berisi setuju atau menolak anjuran. Pihak yang tidak memberikan jawaban, dianggap menolak anjuran. Selanjutnya apabila anjuran pegawai perantara diterima maka dibuat perjanjian bersama untuk didaftarkan ke pengadilan hubungan industrial guna mendapatkan akta bukti pendaftaran.

Penyelesaian melalui konsiliasi, konsiliasi adalah penyelesaian hubungan industrial melalui musyawarah yang ditengahi oleh seorang atau lebih konsiliator yang netral. Prosedur konsiliasi tidak berbeda dengan mediasi, yaitu menyelesaikan perselisihan diluar pengadilan untuk tercapainya kesepakatan, menyangkut perselisihan kepentingan, perselisihan pemutusan hubungan kerja atau perselisihan antar serikat buruh/ pekerja dalam satu perusahaan oleh konsiliator.

Konsiliator yaitu seseorang atau lebih yang diberikan kewenagan untuk menyelesaikan per- 
selisihan industrial yang wajib memberikan anjuran tertulis kepada para pihak yang berselisih. Bebeda dengan mediator, seorang konsiliator bukan berstatus sebagai karyawan atau pegawai pemerintah. Konsiliator dapat memberikan konsiliasi setelah memperoleh izin dan terdaftar dikantor instansi yang bertanggung jawab dibidang ketenagakerjaan kabupaten atau kota.

Penyelesaian melalui arbitrase, istilah arbitrase berasal dari kata arbitrare (bahasa latin) yang berarti kekuasaan untuk menyelesaikan sesuatu perkara menurut kebijaksanaan. Dihubungkannya arbitrase dengan kebijaksanaan tersebut dapat menimbulkan kesan seolah seorang arbiter atau majelis arbiter dalam menyelesaikan suatu sengketa tidak berdasarkan norma-norma hukum lagi dan menyandarkan pemutusan sengketa tersebut hanya kepada kebijaksanaan saja.

Namun sebenarnya kesan tersebut keliru karena arbiter atau majelis arbiter tersebut juga menerapkan hukum seperti halnya yang dilakukan oleh hakim atau pengadilan. Arbitrase adalah penyelesaian atau pemutusan sengketa oleh seorang hakim atau para hakim yang bertujuan mereka akan tunduk kepada atau mentaati keputusan yang telah diberikan oleh hakim atau para hakim yang mereka pilih atau tunjuk tersebut.

Penyelesaian perselisihan perburuhan melalui jalur pengadilan hubungan industrial. Penyelesaian perselisihan hubungan industrial melalui Pengadilan Hubungan Industrial diawali dengan mengajukan gugatan kepada pengadilan hubungan industrial pada pengadilan 'negeri yang daerah hukumnya meliputi tempat pekerja/buruh bekerja. Pengajuan gugatan harus dilampiri risalah penyelesaian melalui mediasi atau konsiliasi, jika tidak dilampiri maka hakim wajib mengembalikan gugatan kepada penggugat. Terhadap isi gugatan ada kewajiban.

Hakim untuk memeriksa melalui proses dismissal. Pemeriksaan perkara di pengadilan hubungan industrial dilakukan dengan acara biasa atau acara cepat. Putusan majelis hakim wajib diberikan selambat-lambatnya lima puluh hari kerja sejak sidang pertama dalam sidang terbuka untuk umum. Putusan pengadilan hubungan industrial mengenai perselisihan hak dan perselisihan pemutusan hubungan kerja mempunyai kekuatan hukum tetap apabila tidak dhajukan permohonan kasasi kepada mahkamah Agung dalam waktu selambatlambatnya empat belas hari. Penyelesaian perselisihan hubungan industrial pada Mahkamah Agung selambat-lambatnya tiga puluh kerja.

Perlunya dicermati bahwa upaya penyelesaian di luar pengadilan ternyata memiliki keterkaitan dengan mekanisme penyelesaian melalui pengadilan sebagaimana diatur dalam Pasal 83 ayat (1) UU Nomor 2 Tahun 2004 yang berbunyi sebagai berikut: "Pengajuan gugatan yang tidak dilampiri risalah penyelesaian melalui mediasi atau konsiliasi, maka hakim Pengadilan Hubungan Industrial wajib mengembalikan gugatan kepada penggugat". (Ernama, 2016)

\section{Simpulan}

Pengaturan mengenai pekerja/buruh harian lepas diatur di dalam Peraturan perundangundangan, di dalam undang-undang nomor 13 tahun 2003 tentang ketenagakerjaan di dalam Pasal 56 sampai dengan Pasal 59, namun terdapat beberapa pasal yang diubah oleh Undang-undang Nomor 11 Tahun 2020 tentang cipta kerja, namun untuk peraturan pemerintah yang diamanatkan di dalam Pasal 81 angka 15 ayat (4) Undang-undang Nomor 11 Tahun 2020 tentang cipta kerja, masih belum dikeluarkan sehingga peraturan pelaksana yang mengatur mengenai pekerja harian lepas masih menggunakan ketentuan Keputusan Menteri Tenaga Kerja dan Transmigrasi Republik Indonesia Nomor Kep.100/MEN/VI/2004 tentang Ketentuan Pelaksanaan Perjanjian Kerja Waktu Tertentu dimana pekerja harian lepas diatur di dalam Pasal 10 sampai dengan Pasal 12. 


\section{Jurnal Cakrawala Hukum, Volume 12 No. 2 Agustus 2021}

ISSN PRINT 2356-4962 ISSN ONLINE 2598-6538

Penyelesaian sengketa antara pengusaha dengan pekerja/buruh harian lepas dapat diselesaikan dahulu secara musyawarah untuk mufakat sesuai dengan yang sudah diatur di dalam Pasal 136 ayat (1) Undang-Undang Nomor 13 Tahun 2003 tentang Ketenagakerjaan, namun apabila upaya musyawarah untuk mufakat tidak tercapai maka pengusahan dan pekerja/buruh atau serikat pekerja/serikat buruh menyelesaikan perselisihan hubungan industrial melalui prosedur yang diatur undang-undang sebagaimana yang tercantum dalam Pasal 136 ayat (2) Undang-Undang Nomor 13 Tahun 2003 tentang. Ketenagakerjaan.

\section{Daftar pustaka}

Agus, Dwiyanto. 2006. Reformasi Birokrasi Publik di Indonesia. Yogyakarta: Gadjah Mada University Press.

Asikin, Zainal. 2006. Dasar-Dasar Hukum Perburuhan. Jakarta: Raja Grafindo Persada.

Bambang, R. Joni. 2013. Hukum Ketenagakerjaan. Bandung: Pustaka Setia.
Ernama, Budiharto, Hendro. Pengawasan Otoritas Jasa Keuangan Terhadap Financial Technology (Peraturan Otoritas Jasa Keuangan Nomor 77/ POJK.01/2016). Diponegoro Law Journal.

Hakim, Abdul. 2009. Dasar-Dasar Hukum Ketenagakerjaan di Indonesia. Bandung: Citra Aditya Bakti.

Husni, Lalu. 2003. Pengantar Hukum Ketenagakerjaan Indonesia. Jakarta: Grafindo Persada Mataram.

Husni, Lalu. 2005. Penyelesaian Perselisishan Hubungan Industrial Melalui Pengadilan dan di Luar Pengadilan. Jakarta: Raja Grafindo Persada.

Midah, Agus. 2010. Hukum Ketenagakerjaan Indonesia Dinamika dan Kajian Teori. Bogor: Ghalia Indonesia.

Prinst, Darwin. 2000. Hukum Ketenagakerjaan Indonesia. Bandung: Citra.

Partanto, Pius. 2001. Kamus Ilmiah Popular. Surabaya: Arkola.

Prodjodikoro, Wirjono. 2008. Asas-Asas Hukum Pidana Di Indonesia. Jakarta: Refika Aditama.

Suwarno. 2000. Hubungan Industrial Dalam Praktek. cet. 1. Jakarta: Asosiasi Hubungan Industrial Indonesia. 